\title{
Bryoliths (Bryozoa) in the Gulf of California ${ }^{1}$
}

\author{
D. W. Fames, ${ }^{2,4}$ M. S. Foster, ${ }^{2}$ and F. O'Sullivan ${ }^{3}$
}

\begin{abstract}
Populations of Diaperoforma californica (d'Orbigny) bryoliths were discovered in rhodolith beds, a sand habitat, and on a cobble bottom in the Gulf of California, Mexico, the first known observation of a modern free-living cyclostome bryozoan in the Northern Hemisphere. Densities ranged from a mean of 9.2 to 22.6 individuals $/ 0.06 \mathrm{~m}^{2}$. Bryoliths from the deepest site were irregularly shaped and had the highest variation in shape; those from shallow sites were spheroidal. Water motion and bioturbation move the bryoliths and may determine their morphology. Schizomavella robertsonae (Soule, Soule \& Chaney) bryoliths also occurred occasionally in one rhodolith bed sampled. Fossilized bryolith specimens of the cyclostome Diaperoforma californica (d'Orbigny) were found in a Pleistocene deposit near modern habitats.
\end{abstract}

Bryoliths (free-living bryozoans that colonize and surround a pebble, shell fragment, and other objects or are formed by fragmentation and regeneration) (Cook 1963, Winston and Håkansson 1986, Kvitek 1989), algae (Bosence 1983), and coral (Glynn 1974, Scoffin et al. 1985) are known to occur worldwide on soft bottoms. Cheilostome and ctenostome bryoliths are found on sand and shell-gravel substrates. The Gulf of California contains very large populations of rhodoliths (unattached nongeniculate coralline algae) (Foster et al. 1997), coralliths (freeliving coral) (Reyes-Bonilla et al. 1997), and, as reported here, modern bryoliths in some locations. In addition, fossil cheilostome bryozoans from upper Pliocene deposits in the Loreto Basin (Cuffey and Johnson 1997, Dorsey and Kidwell 1999) and Pliocene tidal

${ }^{1}$ This work was supported in part by National Geographic Grant No. 5774-96 (to K. Meldahl), InterAmerican Institute Grant No. UCAR 597-74025 (to M.S.F.), and Moss Landing Marine Laboratories. Manuscript accepted 1 March 2005.

${ }^{2}$ Moss Landing Marine Laboratories, 8272 Moss Landing Road, Moss Landing, California 95039.

${ }^{3}$ Monterey Bay Aquarium, 866 Cannery Row, Monterey, California 93940.

${ }^{4}$ Current address: The City of San Diego, Environmental Monitoring and Technical Services Laboratory, 2392 Kincaid Road, San Diego, California 92101.

Pacific Science (2006), vol. 60, no. 1:117-124

(C) 2006 by University of Hawai'i Press

All rights reserved channel deposits of the Imperial Formation of southeastern California (Kidwell and Gyllenhaal 1998) were found.

Attached colonies of the cyclostome bryozoan Diaperoforma californica (d'Orbigny) have been reported from British Columbia to Costa Rica from below the low-tide level to depths over $185 \mathrm{~m}$ and are common in the Gulf of California (Osburn 1953). This species is morphologically plastic, with shapes ranging from short and palmate to tall with slender branches. Habitat may affect the morphology of $D$. californica. The branches are usually narrow in proportion to their length in deeper waters and shorter, wider, and less erect in exposed habitats (Osburn 1953).

We describe this species as a bryolith, the first description of a modern free-living cyclostome bryozoan in the Northern Hemisphere, and present information on its morphology, density, cover, and habitat.

\section{MATERIALS AND METHODS}

\section{Study Sites}

Bryoliths were studied at four sites in the Gulf of California (Figure 1), and densities were estimated at two of these, the rhodolith beds off Punta Chivato (Manto de James) and off Isla Pata in Bahía de Los Angeles. Additional observations and specimens were collected off Isla Pescador in Bahía de Los Angeles and in the Canal de San Lorenzo. Pleistocene Diaperoforma californica (d'Or- 


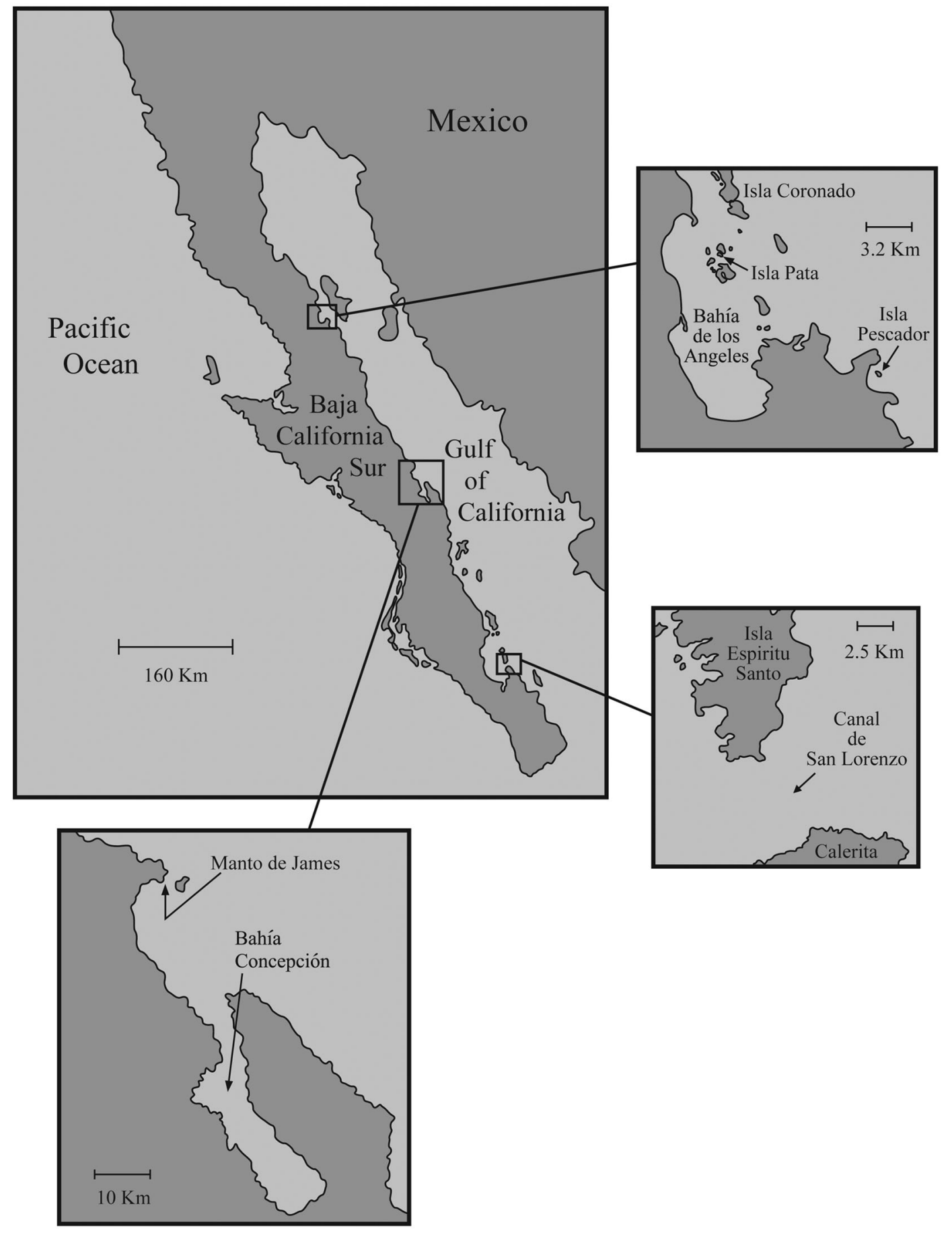

Figure 1. Location of study sites in the Gulf of California, Mexico. 
bigny) fossil specimens were collected at Isla Coronado.

Bryoliths were sampled in the rhodolith bed at Manto de James in March 1997 and June 1997. This rhodolith bed occurred on a shallow $(6.7-7.3 \mathrm{~m})$ flat sandy bottom exposed to strong tidal and wind-driven currents. Bryoliths were mostly Diaperoforma californica (Figure 2A,B,C,E), with Schizomavella robertsonae (Soule, Soule \& Chaney) occurring occasionally (Figure 2D). Rhodoliths consisted of Lithophyllum margaritae (Hariot) Heydrich and Neogoniolithon trichotomun (Heydrich) Setchell \& Mason and covered $50-60 \%$ of the bottom. Sparse foliose red algae were present.

Diaperoforma californica bryoliths were observed on the southwest side of Isla Pescador, Bahía de Los Angeles, in May 1994. High densities of bryoliths $1.5-3 \mathrm{~cm}$ in diameter occurred in $2-3 \mathrm{~m}$ of water in swell troughs on the sand. The troughs were several meters long and located 20-30 m offshore. Various algae, including rhodoliths, and organic debris filled the troughs and covered the bryoliths.

A bryolith field consisting of $D$. californica was sampled at Isla Pata, Bahía de Los Angeles, in June 1998. Bryoliths occurred on a cobble bottom in a band $8.5-11 \mathrm{~m}$ wide and $53 \mathrm{~m}$ long that paralleled the curving shoreline at a depth of $2.4 \mathrm{~m}$ and $15 \mathrm{~m}$ from shore. No rhodoliths were observed.

Diaperoforma californica bryoliths from the Canal de San Lorenzo were collected from a depth of $14 \mathrm{~m}$ in a rhodolith bed between Isla Espíritu Santo and Calerita in June 1997 (rhodolith bed described in Foster et al. [1997]). The rhodolith bed consisted of rhodoliths (primarily Lithophyllum margaritae) grading into white calcareous sand at 12 $19 \mathrm{~m}$ depth.

Bryolith and algal cover was determined at Manto de James in June 1997 using a point quadrat consisting of a $1-\mathrm{m}$ bar with a $1.5-\mathrm{m}$ string attached at both ends with 10 points tied on the string (Foster 1982). Five quadrats were randomly placed and sampling points (total $=20$ ) were positioned on each side of the bar. Bars were placed where the rhodoliths covered $50-60 \%$ of the sand bottom.
All bryoliths, algae, and substrate under each point were recorded. Bryolith density was determined at Manto de James in June 1997 $(n=5)$ and Isla Pata in June $1998(n=10)$. All bryoliths were counted in 0.25 by $0.25 \mathrm{~m}$ randomly placed quadrats.

Sphericity of haphazardly collected bryoliths was calculated to determine if morphology varied among locations. Variation in shape was characterized by measuring the longest dimension (L), the intermediate dimension measured at the widest point $90^{\circ}$ to the midpoint of the axis of $\mathrm{L}(\mathrm{I})$, and the shortest dimension measured at $90^{\circ}$ to the midpoint of I (S). These lengths were measured with a digital caliper (to the nearest $1 /$ 100 of a mm) and were used to calculate the coefficient of variation $(\mathrm{CV}$; sample standard deviation/mean of L, I, and S multiplied by $100 ; n=3$ ), a measure of sphericity (Foster et al. 1997).

The difference between individual mean bryolith lengths at Manto de James in March and June was tested for significance (independent sample $t$-test) based on the means of all three axes. The means were $\log (\mathrm{X})$ transformed to satisfy the assumption of normality. Normality was determined graphically, and homogeneity of variances was tested using the $F$ test (Zar 1984).

Differences in bryolith sphericity (CV) among sites were tested with analysis of variance (ANOVA). The assumption of normally distributed error terms was tested using a normality plot of residuals. Levene's test revealed minor homoscedasticity of error terms, which was corrected using an arcsine-square root transformation.

\section{RESULTS}

Bryoliths were common in the habitats sampled. The percent cover of bryoliths (mean \% \pm SE) at Manto de James in June was $15 \pm 4 \%$. Rhodolith cover was $64 \pm 6 \%$, foliose red algal cover was $12 \pm 6 \%$, and sand cover was $8 \pm 3 \%$. Bryolith density at Manto de James in June was $9.2 \pm 2.33$ individuals/ $0.06 \mathrm{~m}^{2} \quad($ mean $\pm \mathrm{SE})$ and $22.6 \pm 2.95$ individuals $/ 0.06 \mathrm{~m}^{2}$ at Isla Pata. Although quantitative data were not collected at Isla 


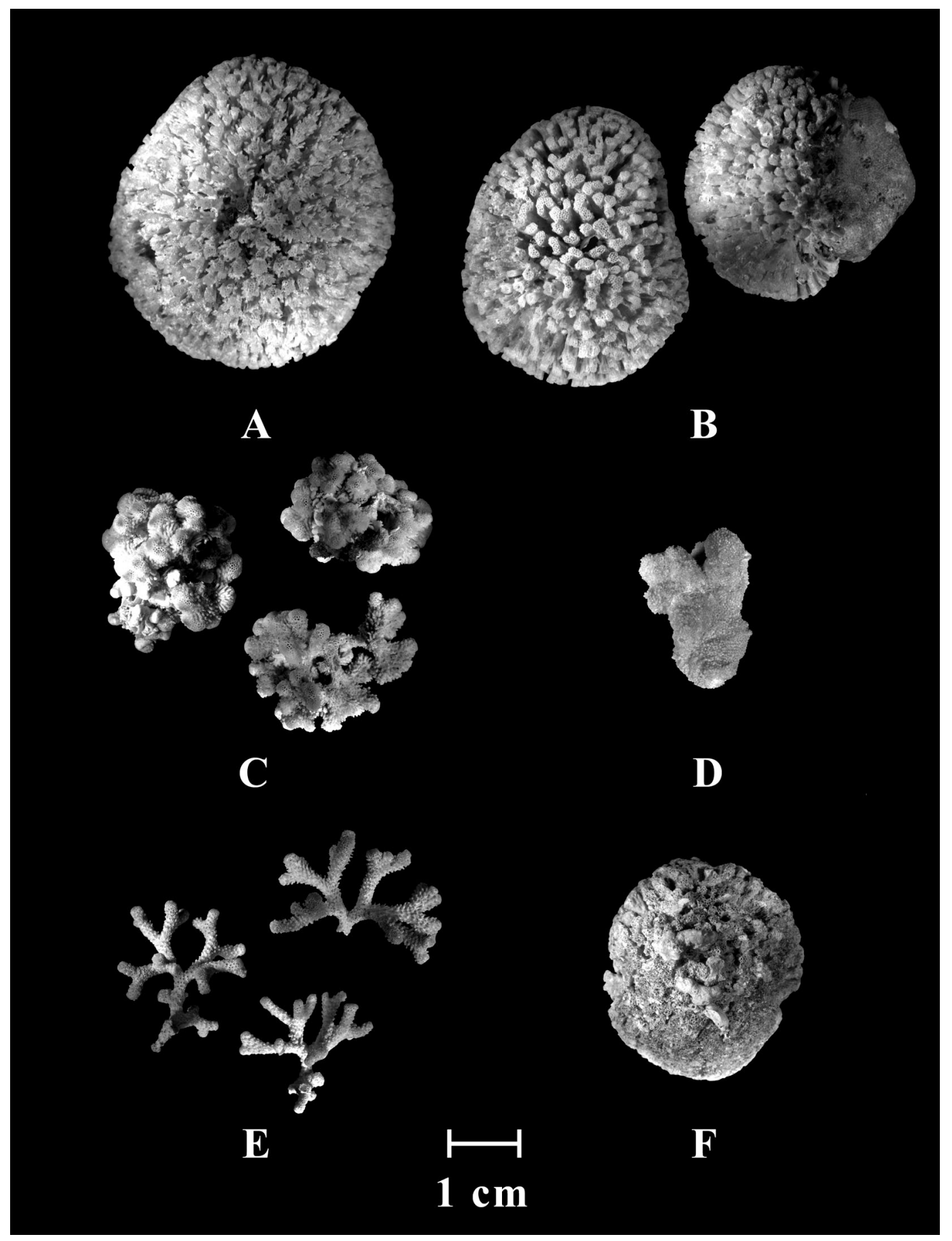

Figure 2. Representative bryoliths from study sites in the Gulf of California. $A$, Isla Pescador; $B$, Isla Pata; $C$, Manto de James; $D$, Manto de James; $E$, Canal de San Lorenzo; F, Isla Coronado (fossil). All are Diaperoforma californica except $D$, which is Schizomavella robertsonae. 
TABLE 1

Shape and Size of Bryoliths

\begin{tabular}{lcccccr}
\hline \hline Site & Depth $(\mathrm{m})$ & Longest Axis & Intermediate Axis & Shortest Axis & CV & $n$ \\
\hline Isla Pata & 2 & $43.69 \pm 2.29$ & $39.35 \pm 2.23$ & $33.82 \pm 2.37$ & $14 \pm 3$ & 9 \\
Manto de James & 7 & $22.89 \pm 1.32$ & $19.46 \pm 1.27$ & $15.89 \pm 1.42$ & $19 \pm 3$ & 6 \\
$\quad$ March & 7 & $17.91 \pm 1.27$ & $14.65 \pm 0.96$ & $11.19 \pm 0.81$ & $23 \pm 2$ & 14 \\
$\quad$ June & $12-19$ & $19.26 \pm 0.55$ & $15.47 \pm 0.71$ & $11.45 \pm 0.69$ & $27 \pm 3$ & 20 \\
San Lorenzo & &
\end{tabular}

Note: Lengths, mean \pm SE mm (untransformed data); CV, coefficient of variation (\%; mean \pm SE; untransformed data). Sphericity increases as CV decreases.

Pescador and the Canal de San Lorenzo, bryoliths were abundant at Isla Pescador but rare at the Canal de San Lorenzo.

Bryoliths differed in size and shape at the various sites (Figure 2). Size (longest dimension) ranged from 30.8 to $56.7 \mathrm{~mm}$ at Isla Pata, 10.9 to $28.3 \mathrm{~mm}$ at Manto de James, and 14.1 to $22.8 \mathrm{~mm}$ at San Lorenzo (Table 1). Bryoliths from Isla Pata and Isla Pescador (visual observation only) were highly spheroidal; those from Manto de James were mostly spheroidal with some elongation of branches. Bryoliths from San Lorenzo were highly branched, irregularly shaped, and had a tendency toward spheroidal shapes. Bryoliths from Isla Pata were the largest and had the lowest CV (Table 1). The mean size of bryoliths at Manto de James in June was significantly smaller than in March (all three axes used to determine mean; independent sample $t$-test: $t=2.75, \mathrm{df}=18, P=0.013)$.

A significant difference was found among sites for the CV (ANOVA: $F=4.89$; $\mathrm{df}=3$, $45 ; P=0.005$ ). Post hoc tests showed that the $\mathrm{CV}$ for bryoliths at Isla Pata was significantly smaller than those for Manto de James in March $(P=0.045)$ and San Lorenzo $(P=0.003)$. There was no significant difference between the CVs for bryoliths at Manto de James in March and June $(P=0.739)$. The high CV at San Lorenzo reflects the observation of irregular bryolith shapes in this current bed.

The fossil Diaperoforma californica was highly spheroidal (Figure $2 F$ ). The size, shape, and morphology of the fossil D. californica are similar to those of the D. californica bryoliths from both Isla Pescador and Isla Pata.

\section{DISCUSSION}

Although there are numerous species of freeliving cheilostomate bryozoans, this record of Diaperoforma californica is the first known record of a modern free-living cyclostome bryozoan occurring in the Northern Hemisphere. Taylor and Gordon (2003) found a modern cyclostome bryolith from New Zealand. Other free-living benthic cheilostomate bryozoans occur on sand (Cook 1963, Cook and Chimonides 1978, Winston and Håkansson 1986, Kvitek 1989), but D. californica is unique in that it occurs on and around hard substrates, such as rhodoliths and cobble, as well as on sand. Rhodoliths and free-living hermatypic corals, in addition to the aforementioned bryoliths, occur together on sand bottoms in the Gulf of California (Steller and Foster 1995, Foster et al. 1997, ReyesBonilla et al. 1997).

Conditions in the Gulf of California are favorable for the propagation of free-living species. The formation and turning of rhodoliths and coralliths in the region are caused by wave action, currents, and bioturbation (Steller and Foster 1995, Foster et al. 1997, Reyes-Bonilla et al. 1997, Marrack 1999, James 2000). Bryoliths may also be formed by these processes. The presence of bryoliths with nuclei such as small pebbles at Isla Pata and Isla Pescador indicates that water motion may have caused them to be moved about and develop a spheroidal shape after initial settlement on their 
substrate. At Manto de James, bryoliths were observed being bioturbated by the sea urchin Toxopneustes roseus and crabs. Currents were often quite strong at Manto de James and Canal de San Lorenzo ( $25 \mathrm{~cm} / \mathrm{sec}$ [Marrack 1999]) and may have been sufficient to occasionally move bryoliths.

Bryoliths and bryozoans are known to reproduce through fragmentation by physical and biological processes and asexual regeneration in addition to larval development (Blake 1976, McKinney 1983, Winston and Håkansson 1986, Kvitek 1989, Ostrovsky 1997). Bryoliths at Manto de James were significantly smaller in June 1997 than in March 1997 and appear to have fragmented, perhaps by a storm event and/or bioturbation. It is highly likely that these fragments survived because many healthy bryoliths at Manto de James showed evidence of breakage. The majority of the bryolith population at San Lorenzo probably also propagate through fragmentation. All of the bryoliths collected at this site had fragments missing from breakage. These bryoliths were similar to a population of the free-living bryozoan Selenaria in New Zealand, where all colonies had developed from regeneration (Cook and Chimonides 1978).

Vegetative reproduction through fragmentation may be the most favorable form of reproduction for bryozoans living on soft sediments. Reproduction through fragmentation may counteract high larval and juvenile mortality and allow rapid recovery from episodic storm disturbances. Asexual reproduction is highly developed in free-living corals (Highsmith 1982) and free-living bryozoans (Winston 1988) living on sandy substrates.

The branching pattern and shape of the bryolith Diaperoforma californica may increase its survival. Coral fragments well developed in three dimensions are most conducive to survival after being broken off the main colony and lying on sand (Highsmith 1982). The same should hold true for D. californica, because part of a bryolith fragment would be off the substrate regardless of how it was resting on the bottom, making it less likely to be buried or scoured. Bryoliths at Canal de San Lorenzo resembled the fruticose rhodoliths there. This morphology is more stable than densely branched forms (Bosence 1983) and may reduce movements by strong currents.

Although most bryoliths in the Gulf of California likely grew from regenerated fragments, bryoliths may form from larvae that settle on sand and gravel grains and other hard particulate substrates (Rider and Enrico 1979, Winston and Håkansson 1986, Winston 1988). Occasional bryoliths were observed growing on rhodoliths at Manto de James. Bryoliths were present at Isla Pescador and Isla Pata that formed by larvae settling on rocks or pebbles.

Although bryoliths were occasionally buried under rhodoliths, they appeared healthy. Live encrusting bryozoans have been found living $16 \mathrm{~cm}$ below the surface in sandy sediments (Winston and Håkansson 1986), and bryozoans are capable of feeding with their lophophores in interstitial spaces (Håkansson and Winston 1985). Water-born food may still reach bryoliths buried under rhodoliths and enable them to survive burial until being moved back to the surface through bioturbation or water motion. Bryoliths are much lighter than rhodoliths and should end up above rhodoliths after both are disturbed.

The trends in the coefficient of variation suggest that higher variation occurs in deeper habitats dominated by currents. This is similar to the results of Foster et al. (1997) for rhodoliths, where the highest coefficients of variation occurred in the San Lorenzo rhodolith bed, as well as other current beds. The highly branched shape of bryoliths at San Lorenzo may reduce water drag and allow individuals to lock together and prevent them from being swept out of the area by currents.

The spherical shape of bryoliths at Isla Pescador and Isla Pata may be caused by more frequent turning. Sphericity in bryoliths (Rider and Enrico 1979), rhodoliths (Bosellini and Ginsburg 1971, Bosence 1976), and coralliths (Glynn 1974) is thought to be, in part, related to turning frequency. Corallith survival was found to be positively correlated with sphericity and may confer a selective advantage for individuals living in disturbed habitats (Lewis 1989). The spheroi- 
dal shape of these individuals may enable them to survive rolling about in swell troughs.

Bryozoan growth form should assist in facies analyses of fossil deposits. The discovery of a fossil cyclostome bryolith Diaperoforma californica indicates that these bryoliths have been present in the Gulf of California since at least the Pleistocene. Previous facies analyses (except Balson and Taylor [1982]) have not considered the existence of free-living cyclostome bryozoans. Diaperoforma californica bryoliths are an exception to current classifications and models of bryozoan growth forms (Nelson et al. 1988, Bone and James 1993, Hageman et al. 1997).

Bryolith growth form may aid in reconstructing the habitat in which they lived. Fossil bryoliths with a high coefficient of variation may be indicative of deep habitats that were dominated by currents. Balson and Taylor (1982) found four species of fossil cyclostome bryoliths from the Coralline Crag (Pliocene formation) that were usually spheroidal in shape. These bryoliths were present in facies where bioturbation may have resulted in their turning but were absent in turbulent sandwave facies.

\section{ACKNOWLEDGMENTS}

Many thanks to Rafael Riosmena-Rodriquez for his collaboration and logistical support, Judy Winston for her bryozoan identifications, and Rick Rowe for his digital photography.

\section{Literature Cited}

Balson, P. S., and P. D. Taylor. 1982. Palaeobiology and systematics of large cyclostome bryozoans from the Pliocene Coralline Crag of Suffolk. Palaeontology (Lond.) 25:529-554.

Blake, D. B. 1976. Functional morphology and taxonomy of branch dimorphism in the Paleozic bryozoan genus Rbabdomeson. Lethaia 9:169-178.

Bone, Y., and N. P. James. 1993. Bryozoans as carbonate sediment producers on the cool-water Lacepede Shelf, southern Australia. Sediment. Geol. 86:247-271.
Bosellini, A., and R. N. Ginsburg. 1971. Form and internal structure of recent algal nodules (rhodolites) from Bermuda. J. Geol. 79:669-682.

Bosence, D. W. J. 1976. Ecological studies on two unattached coralline algae from western Ireland. Palaeontology 19:365395.

1983. The occurrence and ecology of recent rhodoliths: A review. Pages 225242 in T. M. Peryt, ed. Coated grains. Springer-Verlag, Berlin.

Cook, P. L. 1963. Observations on live lunulitiform zoaria of Polyzoa. Cah. Biol. Mar. 4:407-413.

Cook, P. L., and P. J. Chimonides. 1978. Observations on living colonies of Selenaria (Bryozoa, Cheilostomata). I. Cah. Biol. Mar. 19:147-158.

Cuffey, R. J., and M. E. Johnson. 1997. Bryozoan nodules built around andesite clasts from the upper Pliocene of Baja California: Paleoecological implications and closure of the Panama Isthmus. Pages 111-117 in M. E. Johnson and J. Ledesma-Vázquez, eds. Pliocene carbonates and related facies flanking the Gulf of California, Baja California Sur, Mexico. Geol. Soc. Am. Spec. Pap. 318.

Dorsey, R. J., and S. M. Kidwell. 1999. Mixed carbonate-siliciclastic sedimentation on a tectonically active margin: Example from the Pliocene of Baja California Sur, Mexico. Geology 27:935-938.

Foster, M. S. 1982. The regulation of macroalgal associations in kelp forests. Pages 185-205 in L. Srivastava, ed. Synthetic and degradative processes in marine macrophytes. Walter DeGruyter, Berlin.

Foster, M. S., R. Riosmena-Rodriguez, D. L. Steller, and W. J. Woelkerling. 1997. Living rhodolith beds in the Gulf of California and their implications for paleoenvironmental interpretation. Pages 127139 in M. E. Johnson and J. LedesmaVázquez, eds. Pliocene carbonates and related facies flanking the Gulf of California, Baja California Sur, Mexico. Geol. Soc. Am. Spec. Pap. 318.

Glynn, P. W. 1974. Rolling stones among the Scleractinia: Mobile coralliths in the 
Gulf of Panama. Proc. 2nd Int. Coral Reef Symp. 2:183-198.

Hageman, S. J., Y. Bone, B. McGowran, and N. P. James. 1997. Bryozoan colonial growth-forms as paleoenvironmental indicators: Evaluation of methodology. Palaios 12:405-419.

Håkansson, E., and J. E. Winston. 1985. Interstitial bryozoans: Unexpected life forms in a high energy environment. Pages 125134 in C. Nielsen and G. P. Larwood, eds. Bryozoa: Ordovician to Recent. Olsen \& Olsen, Fredensborg, Denmark.

Highsmith, R. C. 1982. Reproduction by fragmentation in corals. Mar. Ecol. Prog. Ser. 7:207-226.

James, D. W. 2000. Diet, movement, and covering behavior of the sea urchin Toxopneustes roseus in rhodolith beds in the Gulf of California, Mexico. Mar. Biol. (Berl.) 137:913-923.

Kidwell, S. M., and E. D. Gyllenhaal. 1998. Symbiosis, competition, and physical disturbance in the growth histories of Pliocene cheilostome bryoliths. Lethaia 31:221-239.

Kvitek, R. G. 1989. Hydrodynamic morphology and behavior of a free-living sedimentdwelling bryozoan, Alcyonidium disciforme (Smitt). J. Exp. Mar. Biol. Ecol. 125:1332.

Lewis, J. B. 1989. Spherical growth in the Caribbean coral Siderastrea radians (Pallas) and its survival in disturbed habitats. Coral Reefs 7:161-167.

Marrack, E. C. 1999. The relationship between water motion and living rhodolith beds in the southwestern Gulf of California, México. Palaios 14:159-171.

McKinney, F. K. 1983. Asexual colony multiplication by fragmentation: An important mode of genet longevity in the carboniferous bryozoan Archimedes. Paleobiology 9:35-43.

Nelson, C. S., F. M. Hyden, S. L. Keane, W. L. Leask, and D. P. Gordon. 1988. Ap- plication of bryozoan zoarial growth-form studies in facies analysis of non-tropical carbonate deposits in New Zealand. Sediment. Geol. 60:301-322.

Osburn, R. C. 1953. Bryozoa of the Pacific coast of America. Part 3. Cyclostomata, Ctenostomata, Entoprocta and Addenda. Allan Hancock Pacific Expeditions 14:613-841.

Ostrovsky, A. N. 1997. Rejuvenation in colonies of some Antarctic tubuliporids (Bryozoa, Stenolaemata). Ophelia 46:175-185.

Reyes-Bonilla, H., R. Riosmena-Rodriguez, and M. S. Foster. 1997. Hermatypic corals associated with rhodolith beds in the Gulf of California, México. Pac. Sci. 51:328337.

Rider, J., and R. Enrico. 1979. Structural and functional adaptations of mobile anascan ectoproct colonies (ectoproctaliths). Pages 297-319 in G. P. Larwood and M. B. Abbott, eds. Advances in bryozoology. Academic Press, New York.

Scoffin, T. P., D. R. Stoddart, A. W. Tudhope, and C. Woodroffe. 1985. Rhodoliths and coralliths of Muri Lagoon, Rarotonga, Cook Islands. Coral Reefs 4:71-80.

Steller, D. L., and M. S. Foster. 1995. Environmental factors influencing distribution and morphology of rhodoliths in Bahia Concepcion, B.C.S., Mexico. J. Exp. Mar. Biol. Ecol. 194:201-212.

Taylor, P. D., and D. P. Gordon. 2003. Endemic new cyclostome bryozoans from Spirits Bay, a New Zealand marinebiodiversity "hotspot." N. Z. J. Mar. Freshwater Res. 37:653-669.

Winston, J. E. 1988. Life histories of freeliving bryozoans. Natl. Geogr. Res. 4:528-539.

Winston, J. E., and E. Håkansson. 1986. The interstitial bryozoa fauna from Capron Shoal, Florida. Am. Mus. Novit. 2865:150.

Zar, J. H. 1984. Biostatistical analysis. Prentice Hall, Englewood Cliffs, New Jersey. 